\title{
PENGARUH KOMBINASI NaOH DAN SUHU BERBEDA TERHADAP NILAI DERAJAT DEASETILASI KITOSAN DARI CANGKANG KERANG KAMPAK (Atrina pectinata)
}

\section{The Influence of $\mathrm{NaOH}$ and Temperature on The Degree of Deacetylation of Chitosan from Pen Shells (Atrina pectinata)}

\author{
Anggun Nurani Citrowati ${ }^{1 *}$, Woro Hastuti Satyantini ${ }^{2}$ dan Gunanti Mahasri ${ }^{2}$ \\ ${ }^{1}$ Program Studi Budidaya Perairan, Fakultas Perikanan dan Kelautan, Universitas Airlangga, Surabaya \\ ${ }^{2}$ Departemen Manajemen Kesehatan Ikan dan Budidaya Perairan, Fakultas Perikanan dan Kelautan, Universitas \\ Airlangga, Surabaya \\ *anggunnc2@gmail.com
}

\begin{abstract}
Abstrak
Kerang kampak (Atrina pectinata) adalah jenis kerang komoditas perikanan Indonesia yang mengalami kenaikan permintaan tiap tahun. Kerang kampak yang dikonsumsi akan menghasilkan limbah padat berupa cangkang. Secara umum, limbah cangkang kerang memiliki kandungan kitin yang dapat dimanfaatkan lebih lanjut menjadi produk bernilai tinggi yaitu kitosan. Salah satu paramerter penentu kualitas kitosan adalah nilai derajat deasetilasi. Nilai derajat deasetilasi dipengaruhi oleh konsentrasi $\mathrm{NaOH}$ dan suhu yang digunakan pada proses deasetilasi. Semakin tinggi konsentrasi $\mathrm{NaOH}$ dan suhu yang digunakan, semakin tinggi nilai derajat deasetilasi. Akan tetapi, konsentrasi alkali dan suhu yang terlalu tinggi dapat menurunkan rendemen kitosan serta menyebabkan depolimerasi dan degradasi polimer. Kombinasi konsentrasi $\mathrm{NaOH}$ dan suhu proses yang tepat akan menghasilkan kitosan dengan nilai derajat deasetilasi yang tinggi dan mutu yang baik. Tujuan dari penelitian ini adalah mengetahui pengaruh dan perlakuan terbaik dari kombinasi $\mathrm{NaOH}$ dan suhu berbeda terhadap nilai derajat deasetilasi kitosan yang dihasilkan dari cangkang kerang kampak. Penelitian ini menggunakan metode Rancangan Acak lengkap (RAL) faktorial yang terdiri dari dua kombinansi faktor perlakuan yaitu konsentrasi $\mathrm{NaOH}(50 \%, 55 \%$ dan $60 \%)$ dan suhu $\left(100^{\circ} \mathrm{C}\right.$ dan $\left.130^{\circ} \mathrm{C}\right)$ dengan tiga kali ulangan. Hasil penelitian menunjukkan bahwa kombinasi $\mathrm{NaOH}$ dan suhu pada proses deasetilasi tidak berpengaruh nyata terhadap nilai derajat deasetilasi kitosan. Kesimpulan dari penelitian ini menunjukkan bahwa deasetilasi menggunakan perlakuan kombinasi $\mathrm{NaOH} 55 \%$ dan suhu $100^{\circ} \mathrm{C}$ merupakan perlakuan yang cukup baik untuk menghasilkan kitosan dari cangkang kerang kampak yang menghasilkan nilai derajat deasetilasi sebesar $71,70 \%$, rendemen sebesar $47,25 \%$, kadar abu sebesar $84,32 \%$ dan kadar air sebesar $0,25 \%$.
\end{abstract}

Kata Kunci: Limbah, Kerang Kampak, Kitosan, Nilai Derajat Deasetilasi, Atrina Pectinata

\begin{abstract}
Pen shells (Atrina pectinata) is one of Indonesia's fishery comodity that receives an increase of demand every year. The consumed pen shells may produce solid waste from it shells. Generally, shell waste contains some amount of chitin, so it can be transformed into a higher value product, that is chitosan. One of main parameters that can determine the quality of chitosan is degree of deacetylation. Degree of deacetylation can be influenced by $\mathrm{NaOH}$ concentration and temperature that are used during deacetylation process. The higher $\mathrm{NaOH}$ concentration and temperature the more degree of deacetylation. However, $\mathrm{NaOH}$ concentration and temperature that are too high may decrease the yield of chitosan and lead to depolimeryzation and degradation. Proper combination of $\mathrm{NaOH}$ and temperature will produce chitosan with higher degree of deacetylation and quality. The aim of this research is to find out about the influence and the best treatment of $\mathrm{NaOH}$ concentration and temperature on the degree of deacetylation of chitosan from pen shells. This research uses Completely Randomized Design (CRD) factorial consisting of two factors, there are $\mathrm{NaOH}$ concentration $(50 \%, 55 \%$ and $60 \%)$ and temperature $\left(100^{\circ} \mathrm{C}\right.$ and $\left.130^{\circ} \mathrm{C}\right)$ with three replications. The result shows that there is no significantly difference between combination of $\mathrm{NaOH}$ and temperature on the degree of deacetylation of chitosan from pen shells. The conclusion of this research shows that deacetylation using $55 \% \mathrm{NaOH}$ and $100^{\circ} \mathrm{C}$ have better result to produce chitosan with $71,70 \%$ degree of deacetylation, $47,25 \%$ yield, $84,32 \%$ ash content, and 0,25 water content.
\end{abstract}

Keywords: Waste, Pen Shells, Chitosan, Degree of Deacetylation, Atrina Pectinata 


\section{PENDAHULUAN}

Kerang merupakan salah satu komoditas perikanan Indonesia yang mengalami kenaikan permintaan tiap tahunnya (Cakasana dkk., 2014). Salah satu jenis kerang yang menjadi komoditas tersebut adalah kerang kampak. Jenis kerang tersebut banyak terdapat di Pantai Kenjeran, Jawa Timur. Berdasarkan survei yang dilakukan pada tahun 2013, kerang tersebut merupakan salah satu sumberdaya perikanan yang paling banyak didapatkan oleh nelayan Surabaya yaitu sebesar 331,3 ton (Subagiyo dan Widagdo, 2014). Daging kerang dikonsumsi oleh masyarakat lokal sedangkan limbah padat berupa cangkang dibuang di pesisir pantai. Limbah cangkang kerang tersebut perlu dilakukan penanganan yang tepat karena berpotensi untuk dimanfaatkan menjadi produk yang bernilai jual tinggi. Secara umum, cangkang kerang adalah salah satu bahan baku perikanan yang memiliki kandungan kitin sehingga limbah cangkang tersebut dapat diolah lebih lanjut menjadi produk yang bernilai tinggi yaitu kitosan (Hastuti dan Tulus, 2015). Saat ini telah dilakukan beberapa penelitian mengenai pemanfaatan cangkang kerang sebagai bahan baku untuk memproduksi kitosan. Cangkang kerang yang digunakan pada penelitian tersebut diantaranya adalah kerang hijau (Sinardi dkk., 2013), kerang simping (Sulistyoningrum dkk., 2013; Cakasana dkk., 2014), abalon (Wahyuni dkk., 2008) dan kerang bulu (Hastuti dan Tulus, 2015). Penelitian yang membahas tentang pemanfaatan cangkang kerang kampak sebagai kitosan masih belum ada. Berdasarkan penelitian-penelitian tersebut terdapat potensi untuk memanfaatkan cangkang kerang kampak sebagai bahan baku dalam produksi kitosan.

Kitosan memiliki gugus amina ($\mathrm{NH}_{2}$ ) sehingga bersifat kationik dan dapat terkonversi menjadi polielektrolit pada media asam (Rinaudo, 2006). Sifat polielektrolit kationik kitosan tersebut berfungsi sebagai donor eletron serta adanya gugus amina dan hidroksil membuat kitosan menjadi reaktif untuk digunakan pada beberapa aplikasi (Sinardi dkk., 2013). Kitosan didapatkan melalui proses deasetilasi yaitu dengan melarutkan kitin menggunakan pelarut alkali (umumnya $\mathrm{NaOH}$ ) dengan konsentrasi tinggi dan suhu tinggi (Tanasale, 2010). Fungsi $\mathrm{NaOH}$ adalah untuk memutus ikatan antar karbon pada gugus asetil $\left(-\mathrm{CH}_{3} \mathrm{COO}\right)$ dengan nitrogen yang ada pada kitin sehingga gugus asetil akan terlepas kemudian terjadi pembentukan gugus amina $\left(-\mathrm{NH}_{2}\right)$ sedangkan suhu proses berfungsi untuk mempercepat laju reaksi yaitu dengan meningkatkan gerak molekul $\mathrm{NaOH}$ sehingga kecepatan pemutusan gugus asetil juga akan semakin meningkat (Mastuti, 2005). Presentase gugus asetil yang hilang selama proses deasetilasi disebut sebagai nilai derajat deasetilasi (Apriani dkk., 2012).

Secara teori, semakin tinggi konsentrasi $\mathrm{NaOH}$ dan suhu proses yang digunakan pada proses deasetilasi, semakin tinggi pula nilai derajat deasetilasi sehingga mutu kitosan juga akan semakin tinggi (Tanasale, 2010). Akan tetapi, konsentrasi alkali dan suhu yang terlalu tinggi dapat menurunkan rendemen kitosan serta menyebabkan depolimerasi dan degradasi polimer (Azhar, 2010; Rokhiati, 2004). Kombinasi konsentrasi $\mathrm{NaOH}$ dan suhu proses yang tepat akan menghasilkan kitosan dengan nilai derajat deasetilasi yang tinggi dan mutu yang baik.

\section{METODOLOGI}

\section{Waktu dan Tempat}

Penelitian ini dilaksanakan pada bulan Juni-Agustus 2016 di Laboratorium Pendidikan Fakultas Perikanan dan Kelautan, Universitas Airlangga, Surabaya.

\section{Materi Penelitian}

Peralatan Penelitian

Alat yang digunakan dalam penelitian ini antara lain adalah timbangan analitik, mesin grinder, water bath, heater, desikator, oven, tanur listrik, spektrofotometer UV, gelas kaca, pengaduk kaca, 
gelas ukur, pipet ukur dan bulb, termometer, $\mathrm{pH}$ meter dan cawan porselen.

Bahan Penelitian

Bahan baku yang digunakan dalam penelitian adalah cangkang kerang kampak yang diperoleh dari Pantai Kenjeran, Jawa Timur, $\mathrm{HCl}, \mathrm{NaOH}$ dan aquades.

\section{Metode Penelitian}

Penelitian ini menggunakan metode Rancangan Acak lengkap (RAL) faktorial yang terdiri dari dua faktor perlakuan yaitu konsentrasi $\mathrm{NaOH}(50 \%, 55 \%$ dan $60 \%)$ dan suhu $\left(100^{\circ} \mathrm{C}\right.$ dan $\left.130^{\circ} \mathrm{C}\right)$ sehingga didapatkan enam kombinasi perlakuan dan masing-masing perlakuan mendapat tiga kali ulangan. Analisis data pada penelitian ini menggunakan Analysis of Variance (ANOVA) dan dilanjutkan Uji Duncan.

\section{Prosedur Kerja \\ Preparasi Cangkang Kerang Kampak}

Cangkang kerang kampak dibersihkan menggunakan sikat hingga daging yang melekat pada cangkang dapat terbuang kemudian dibilas dengan air hingga bersih. Cangkang kerang yang telah bersih dikeringkan dengan dijemur selama satu hari. Penggilingan cangkang dilakukan menggunakan mesin grinder hingga dihasilkan cangkang kerang dengan ukuran 80 mesh.

\section{Pembuatan Kitin}

Proses pembuatan kitin terdiri dari dua tahap dasar yaitu proses demineralisasi dan deproteinasi. Kedua proses tersebut dilakukan pada pembuatan kitin dari cangkang kerang kampak yang mengacu pada metode pembuatan kitin yang telah dilakukan Cakasana dkk. (2014).

Proses demineralisasi dilakukan dengan menggunakan metode yang mengacu pada Cakasana dkk. (2014) dengan modifikasi konsentrasi $\mathrm{HCl}$ dan waktu proses yaitu, cangkang kerang dilarutkan pada $\mathrm{HCl} 1,5 \mathrm{~N}$ dengan perbandingan (1:10) $(\mathrm{w} / \mathrm{v})$, suhu $25-30^{\circ} \mathrm{C}$ selama tiga jam. Hasil proses demineralisasi kemudian dicuci hingga mencapai $\mathrm{pH}$ netral (7-8) kemudian dikeringkan pada oven dengan suhu $60^{\circ} \mathrm{C}$.

Proses deproteinasi dilakukan dengan melarutkan cangkang hasil demineralisasi menggunakan larutan $\mathrm{NaOH} 1 \mathrm{~N}$ dengan perbandingan 1:10 (w/v), suhu $70^{\circ} \mathrm{C}$ pada waterbath selama satu jam. Hasil proses deproteinasi disaring kemudian dilakukan proses pencucian sampai mencapai $\mathrm{pH}$ netral (7-8). Setelah $\mathrm{pH}$ netral, hasil deproteinasi dikeringkan pada oven dengan suhu $60^{\circ} \mathrm{C}$. Cangkang kerang yang telah mengalami proses demineralisasi dan deproteinasi disebut dengan kitin.

\section{Pembuatan Kitosan}

Proses deasetilasi dilakukan menggunakan heater yaitu kitin dilarutkan sebanyak 20 gram pada larutan $\mathrm{NaOH}$ dengan perlakuan yang berbeda $(50 \%, 55 \%$ dan $60 \%)$ dengan perbandingan $1: 20(\mathrm{w} / \mathrm{v})$ pada suhu yang berbeda $\left(100^{\circ} \mathrm{C}\right.$ dan $130^{\circ} \mathrm{C}$ ) selama satu jam. Setelah dilakukan proses deasetilasi kitin maka diperoleh kitosan. Kitosan tersebut dicuci hingga mencapai $\mathrm{pH}$ netral (7-8) kemudian dikeringkan pada oven dengan suhu $60^{\circ} \mathrm{C}$.

\section{Perhitungan Nilai Derajat Deasetilasi Kitosan}

Perhitungan nilai derajat deasetilasi dilakukan dengan menggunakan metode spektofotometer UV yang mengacu pada metode yang telah digunakan oleh Liu et al. (2006). Kitosan ditimbang sebanyak 6 mg kemudian dilarutkan dalam $50 \mathrm{~mL}$ $\mathrm{HCl} 0,1 \mathrm{~N}$. Larutan kitosan tersebut dimasukkan dalam kuvet dan dicatat absorbannya pada panjang gelombang $201 \mathrm{~nm}$. Absorban yang terlihat dimasukkan ke dalam persamaan sebagai berikut.

$D A=\frac{161,1 \times A \times V-0,0218 \times M}{3,361 \times M-42,1 \times A \times V}$
$D D=(1-D A) \times 100 \%$

Keterangan :

DA : derajat asetilasi

DD : derajat deasetilasi

A : absorban 
$\mathrm{V}$ : volume larutan (L)

$\mathrm{M}$ : berat kitosan (mg)

\section{Perhitungan Rendemen Kitosan}

Perhitungan rendemen menunjukkan banyaknya kitosan kering yang dihasilkan dari cangkang kerang yang diproses (Purwanti, 2014). Kitosan yang telah dihasilkan dari proses deasetilasi ditimbang dan dicatat beratnya kemudian dilakukan perhitungan rendemen menggunakan persamaan sebagai berikut.

Rendemen $(\%)=\frac{A}{B} \times 100 \%$

Keterangan :

A : massa kitosan kering (g)

B : massa cangkang kerang yang diproses $(\mathrm{g})$

\section{Perhitungan Kadar Abu Kitosan}

Kadar abu kitosan dihitung menggunakan metode perhitungan kadar abu yang ditetapkan oleh Badan Standardisasi Nasional (2006) yaitu, cawan porselen kosong dikeringkan pada oven dengan suhu $102^{\circ} \mathrm{C}-105^{\circ} \mathrm{C}$ selama satu malam kemudian dimasukkan dalam desikator selama 30 menit lalu ditimbang dan dicatat beratnya. Kitosan ditimbang pada cawan porselen lalu diabukan menggunakan tanur listrik dengan suhu $600^{\circ} \mathrm{C}$ selama enam jam. Hasil kitosan yang telah diabukan dimasukkan dalam desikator selama 30 menit kemudian ditimbang dan dicatat beratnya. Kadar abu dihitung menggunakan persamaan sebagai berikut.

$$
\text { Kadar abu }(\%)=\frac{B-A}{\text { berat sampel }(g)} \times 100 \%
$$

Keterangan :

A : berat cawan porselen kosong (g)

B : berat cawan porselen dengan abu (g)

\section{Perhitungan Kadar Air}

Kadar air kitosan dihitung menggunakan metode perhitungan kadar air yang telah ditetapkan oleh Badan Standardisasi Nasional (2006). Cawan porselen dikeringkan pada oven dengan suhu $102^{\circ} \mathrm{C}-105^{\circ} \mathrm{C}$ selama satu jam kemudian dimasukkan dalam desikator selama 30 menit lalu ditimbang dan dicatat beratnya. Sampel ditimbang pada cawan porselen lalu dikeringkan pada oven dengan suhu $105^{\circ} \mathrm{C}$ selama tiga jam. Sampel kitosan yang telah dikeringkan dimasukkan dalam desikator selama 30 menit kemudian ditimbang dan dicatat beratnya. Kadar air kitosan dihitung dengan persamaan sebagai berikut.

$$
\text { Kadar air }(\%)=\frac{B-C}{B-A} \times 100 \%
$$

Keterangan :

A : berat cawan porselen kosong ( $\mathrm{g}$ )

B : berat cawan porselen dengan kitosan (g)

C : berat cawan porselen dengan kitosan setelah dikeringkan $(\mathrm{g})$

\section{HASIL DAN PEMBAHASAN}

\section{Nilai Derajat Deasetilasi Kitosan}

Nilai derajat deasetilasi yang dihasilkan dari beberapa perlakuan kombinasi $\mathrm{NaOH}$ dan suhu berbeda pada proses deasetilasi kitin menjadi kitosan pada penelitian ini berkisar antara 70,76\%$73,15 \%$. Presentase rata-rata nilai derajat deasetilasi kitosan dapat dilihat pada Tabel 1.

Berdasarkan rata-rata, faktor interaksi kombinasi $\mathrm{NaOH}$ dan suhu yang semakin tinggi menyebabkan peningkatan nilai derajat deasetilasi. Menurut Tanasale (2010), secara teori konsentrasi $\mathrm{NaOH}$ dan suhu yang semakin tinggi dapat meningkatkan nilai derajat deasetilasi. Namun pada perlakuan kombinasi $\mathrm{NaOH} 55 \%$ dan suhu $100^{\circ} \mathrm{C}$ terjadi penurunan nilai derajat deasetilasi sebesar $0,4 \%$. Hal tersebut dapat terjadi karena pada konsentrasi yang lebih tinggi larutan bersifat lebih kental sehingga proses pengadukan pada saat deasetilasi tidak berjalan sempurna. 
Menurut Hargono dkk. (2008), proses pengadukan pada deasetilasi yang tidak sempurna dapat mengakibatkan kitin tidak bereaksi secara maksimal dengan larutan
$\mathrm{NaOH}$ sehingga gugus amina yang terbentuk sedikit dan menghasilkan nilai derajat deasetilasi yang rendah.

Tabel 1. Presentase rata-rata nilai derajat deasetilasi kitosan (\%)

Keterangan: Notasi yang ditunjukkan dengan huruf superscript pada baris dan kolom menunjukkan perbandingan antar perlakuan memiliki perbedaan yang nyata $(\mathrm{P}<0,05)$.

\begin{tabular}{cccc}
\hline Konsentrasi $\mathrm{NaOH}(\mathrm{K})$ & \multicolumn{2}{c}{$\mathrm{Suhu}(\mathrm{S})$} & Rata-rata \\
\cline { 2 - 3 } & $\mathrm{S} 1\left(100^{\circ} \mathrm{C}\right)$ & $\mathrm{S} 2\left(130^{\circ} \mathrm{C}\right)$ & \\
\hline $\mathrm{K} 1(50 \%)$ & $70,76^{\mathrm{a}} \pm 0,47$ & $72,10^{\mathrm{ab}} \pm 0,24$ & $71,43^{\mathrm{x}} \pm 0,80$ \\
$\mathrm{~K} 2(55 \%)$ & $71,70^{\mathrm{ab}} \pm 0,59$ & $72,03^{\mathrm{ab}} \pm 1,31$ & $71,87^{\mathrm{xy}} \pm 0,92$ \\
$\mathrm{~K} 3(60 \%)$ & $72,42^{\mathrm{b}} \pm 1,23$ & $73,15^{\mathrm{b}} \pm 0,24$ & $72,79^{\mathrm{y}} \pm 0,89$ \\
\hline Rata-rata & $71,63 \pm 1,02$ & $72,43 \pm 0,87$ & \\
\hline
\end{tabular}

Faktor konsentrasi $\mathrm{NaOH}$ berpengaruh dalam meningkatkan nilai derajat deasetilasi. Hal tersebut sesuai dengan pernyataan Mastuti (2005) yaitu, konsentrasi $\mathrm{NaOH}$ merupakan faktor penting yang dapat mempengaruhi nilai derajat deasetilasi kitosan karena $\mathrm{NaOH}$ dapat memutus ikatan antar karbon pada gugus asetil dengan atom $\mathrm{N}$ yang ada pada kitin. Apriani (2012) menambahkan, Gugus $\mathrm{OH}^{-}$ pada $\mathrm{NaOH}$ akan berinteraksi dengan gugus asetamida $\left(-\mathrm{NHCOCH}_{3}\right)$ pada kitin yang kemudian menyebabkan reaksi eliminasi gugus asetil $\left(-\mathrm{CH}_{3} \mathrm{COO}\right)$. Reaksi eliminasi tersebut akan membentuk suatu amida yaitu gugus amina yang bermuatan positif $\left(-\mathrm{NH}_{2}\right)$. Penggunaan konsentrasi $\mathrm{NaOH} 60 \%$ menghasilkan nilai derajat deasetilasi tertinggi dibandingkan dengan konsentrasi lain. Menurut Azhar (2010), konsentrasi ion $\mathrm{OH}^{-}$yang semakin tinggi akan semakin meningkatkan interaksi ion dengan gugus asetamida sehingga semakin banyak gugus asetil yang tereliminasi dan semakin banyak gugus amina yang terbentuk sehingga nilai derajat deasetilasi akan semakin tinggi. Nilai derajat deasetilasi yang dihasilkan oleh konsentrasi $\mathrm{NaOH} 60 \%$ tidak berbeda nyata dengan penggunaan konsentrasi $\mathrm{NaOH} 55 \%$. Hal tersebut menandakan bahwa penggunaan konsentrasi $55 \%$ dan $60 \%$ akan cenderung menghasilkan nilai derajat deasetilasi yang sama. Dari segi ekonomis, penggunaan konsentrasi $\mathrm{NaOH}$ 55\% akan lebih efisien untuk digunakan dalam pembuatan kitosan karena dalam konsentrasi yang lebih rendah dapat menghasilkan nilai derajat deasetilasi yang tingi.

Hasil penelitian menunjukkan bahwa pada konsentrasi yang sama, faktor suhu akan menghasilkan nilai derajat deasetilasi yang berbeda. Suhu $100^{\circ} \mathrm{C}$ menghasilkan nilai derajat desetilasi yang lebih rendah dibandingkan dengan suhu $130^{\circ} \mathrm{C}$ yaitu dengan selisih sebesar $0,8 \%$. Menurut Mastuti (2005), suhu pada proses deasetilasi berpengaruh terhadap nilai derajat deasetilasi kitosan yang dihasilkan. Suhu proses deasetilasi yang semakin tinggi akan meningkatkan laju reaksi karena suhu dapat meningkatkan gerak antar molekul sehingga reaksi pemutusan gugus asetil akan berjalan semakin cepat. Namun pada penelitian ini, suhu tidak berpengaruh terhadap nilai derajat deasetilasi kitosan. Hal tersebut menandakan bahwa pada penelitian ini penggunaan suhu $100^{\circ} \mathrm{C}$ maupun suhu $130^{\circ} \mathrm{C}$ akan menghasilkan nilai derajat deasetilasi yang sama. Penggunaan suhu $100^{\circ} \mathrm{C}$ lebih efisien dalam pembuatan kitosan karena waktu yang dibutuhkan untuk proses pemanasan kitosan dalam mencapai suhu $100^{\circ} \mathrm{C}$ lebih cepat sehingga lebih menghemat waktu dan energi namun tetap memiliki nilai derajat deasetilasi 
yang sama tinggi dengan penggunaan suhu $130^{\circ} \mathrm{C}$.

Berdasarkan analisis tersebut, perlakuan kombinasi $\mathrm{NaOH} 55 \%$ dan suhu $100^{\circ} \mathrm{C}$ dianggap sebagai perlakuan yang paling efisien untuk pembuatan kitosan karena untuk faktor konsentrasi $\mathrm{NaOH}$, konsentrasi yang menghasilkan nilai derajat deasetilasi tertinggi adalah konsentrasi $\mathrm{NaOH} 60 \%$ namun tidak berbeda nyata dengan penggunaan konsentrasi $55 \%$ sehingga penggunaan konsentrasi yang lebih rendah akan lebih menghemat biaya dalam pembuatan kitosan. Suhu proses tidak berpengaruh terhadap nilai derajat deasetilasi yang dihasilkan sehingga dipilih suhu yang lebih rendah yaitu $100^{\circ} \mathrm{C}$ karena akan lebih menghemat waktu dan energi namun tetap dapat menghasilkan nilai derajat deasetilasi yang tinggi. Perlakuan kombinasi $\mathrm{NaOH} 55 \%$ dan suhu $100^{\circ} \mathrm{C}$ juga tidak berbeda nyata dengan dengan perlakuan kombinasi $\mathrm{NaOH} 60 \%$ dan suhu $130^{\circ} \mathrm{C}$ sehingga penggunaan konsentrasi dan suhu yang lebih rendah yaitu $\mathrm{NaOH} 55 \%$ dan suhu $100^{\circ} \mathrm{C}$ dapat menghemat biaya produksi kitosan.

\section{Rendemen Kitosan}

Rendemen yang dihasilkan dari proses deasetilasi kitin menjadi kitosan pada penelitian ini berkisar antara 10,86\%$53,65 \%$. Presentase rata-rata rendemen kitosan dapat dilihat pada Tabel 2 sebagai berikut.

Tabel 2. Presentase rata-rata rendemen kitosan (\%)

\begin{tabular}{cccc}
\hline Konsentrasi NaOH (K) & \multicolumn{2}{c}{ Suhu (S) } & Rata-rata \\
\cline { 2 - 3 } & $\mathrm{S} 1\left(100^{\circ} \mathrm{C}\right)$ & $\mathrm{S} 2\left(130^{\circ} \mathrm{C}\right)$ & \\
\hline $\mathrm{K} 1(50 \%)$ & $49,64^{\mathrm{b}} \pm 2,24$ & $10,86^{\mathrm{a}} \pm 5,08$ & $30,25 \pm 21,53$ \\
$\mathrm{~K} 2(55 \%)$ & $47,25^{\mathrm{b}} \pm 7,57$ & $18,40^{\mathrm{a}} \pm 6,29$ & $32,83 \pm 16,98$ \\
$\mathrm{~K} 3(60 \%)$ & $53,65^{\mathrm{b}} \pm 4,38$ & $13,26^{\mathrm{a}} \pm 6,91$ & $33,45 \pm 22,72$ \\
\hline Rata-rata & $50,18 \pm 5,31$ & $14,17 \pm 6,28$ & \\
\hline
\end{tabular}

Keterangan: Notasi yang ditunjukkan dengan huruf superscript pada baris dan kolom menunjukkan perbandingan antar perlakuan memiliki perbedaan yang nyata $(\mathrm{P}<0,05)$.

Hasil penelitian menunjukkan bahwa rendemen kitosan lebih dipengaruhi oleh faktor suhu yaitu suhu $100^{\circ} \mathrm{C}$ menghasilkan rendemen lebih tinggi dibandingkan dengan penggunaan suhu $130^{\circ} \mathrm{C}$. Menurut Tanasale (2010) suhu pemanasan pada proses deasetilasi yang terlalu tinggi akan mendegradasi polimer menjadi polimer yang memiliki berat molekul rendah. Apriani dkk. (2012) menambahkan, suhu dapat mempercepat reaksi deasetilasi namun apabila suhu terlalu tinggi, hal tersebut dapat menyebabkan pelepasan rantai asetilasi yang berlebihan pada kitin sehingga terbentuk partikel-partikel kitosan yang halus yang kemudian ikut terlarut dalam larutan $\mathrm{NaOH}$ selama proses deasetilasi berlangsung dan menyebabkan penurunan massa kitosan. Larutan $\mathrm{NaOH}$ pada suhu yang lebih tinggi yaitu suhu $130^{\circ} \mathrm{C}$ lebih cepat menguap dibandingkan dengan larutan $\mathrm{NaOH}$ pada suhu $100^{\circ} \mathrm{C}$ sehingga larutan $\mathrm{NaOH}$ pada suhu yang lebih tinggi lebih cepat habis dibandingkan dengan penggunaan suhu yang lebih rendah. Menurut Fauzan (2001) kekurangan larutan $\mathrm{NaOH}$ selama proses deasetilasi tersebut akan menyebabkan rusaknya struktur kitosan dan terjadi penurunan rendemen kitosan yang dihasilkan.

Penggunaan suhu $100^{\circ} \mathrm{C}$ dan suhu $130^{\circ} \mathrm{C}$ tidak berpengaruh terhadap nilai derajat deasetilasi namun pada penggunaan suhu $100^{\circ} \mathrm{C}$ kitosan yang dihasilkan memiliki rendemen yang lebih tinggi. Berdasarkan analisis tersebut, penggunaan suhu $100^{\circ} \mathrm{C}$ akan lebih efisien untuk digunakan dalam pembuatan kitosan karena lebih 
menghemat waktu dan energi namun tetap menghasilkan kitosan yang memiliki nilai derajat deasetilasi dan rendemen yang tinggi.

\section{Kadar Abu Kitosan}

Kadar abu kitosan dari hasil penelitian ini berkisar antara 83,49\%-88,83\%. Presentase rata-rata kadar abu kitosan dapat dilihat pada Tabel 3 sebagai berikut.

Tabel 3. Presentase rata-rata kadar abu kitosan (\%)

\begin{tabular}{cccc}
\hline \multirow{2}{*}{ Konsentrasi NaOH $(\mathrm{K})$} & \multicolumn{2}{c}{$\mathrm{Suhu}(\mathrm{S})$} & \multirow{2}{*}{ Rata-rata } \\
\cline { 2 - 3 } & $\mathrm{S} 1\left(100^{\circ} \mathrm{C}\right)$ & $\mathrm{S} 2\left(130^{\circ} \mathrm{C}\right)$ & \\
\hline K1 $(50 \%)$ & $83,49^{\mathrm{a}} \pm 1,47$ & $88,68^{\mathrm{b}} \pm 0,51$ & $86,08^{\mathrm{x}} \pm 3,01$ \\
K2 $(55 \%)$ & $84,32^{\mathrm{a}} \pm 1,25$ & $88,83^{\mathrm{b}} \pm 1,15$ & $86,58^{\mathrm{x}} \pm 2,69$ \\
K3 $(60 \%)$ & $89,22^{\mathrm{b}} \pm 2,03$ & $88,55^{\mathrm{b}} \pm 0,14$ & $88,89^{\mathrm{y}} \pm 1,34$ \\
\hline Rata-rata & $85,68 \pm 3,03$ & $88,69 \pm 0,64$ & \\
\hline
\end{tabular}

Keterangan: Notasi yang ditunjukkan dengan huruf superscript pada baris dan kolom menunjukkan perbandingan antar perlakuan memiliki perbedaan yang nyata $(\mathrm{P}<0,05)$.

Hasil penelitian menunjukkan bahwa faktor konsentrasi $\mathrm{NaOH}$, suhu dan kombinasi $\mathrm{NaOH}$ dengan suhu berpengaruh nyata terhadap kadar abu kitosan yang dihasilkan $(\mathrm{P}<0,05)$. Hasil uji lanjut Duncan menunjukkan konsentrasi $\mathrm{NaOH}$ $60 \%$ menghasilkan nilai kadar abu tertinggi dan berbeda nyata dengan kedua konsentrasi lain. Menurut Fauzan (2001) kadar abu dapat dipengaruhi oleh proses pencucian kitosan pada saat penetralan. Konsentrasi $\mathrm{NaOH}$ yang semakin tinggi akan mempersulit proses penetralan karena kitosan harus dinetralkan lebih lama dibandingkan dengan perlakuan yang menggunakan konsentrasi $\mathrm{NaOH}$ lebih rendah. Proses pencucian yang tidak berjalan maksimal dan tidak mencapai $\mathrm{pH}$ netral akan mengakibatkan atom $\mathrm{Na}$ masih terdapat pada kitosan sehingga ketika dianalisis kadar abu, kitosan memiliki kadar abu yang cukup tinggi.

Perlakuan kombinasi $\mathrm{NaOH} 50 \%$ dan suhu $100^{\circ} \mathrm{C}$ menghasilkan nilai kadar abu terendah $(83,48 \%)$ namun tidak berbeda nyata dengan perlakuan kombinasi $\mathrm{NaOH} 55 \%$ dan suhu $100^{\circ} \mathrm{C}$. Berdasarkan hasil tersebut, perlakuan kombinasi $\mathrm{NaOH}$ $55 \%$ dan suhu $100^{\circ} \mathrm{C}$ lebih efisien digunakan untuk pembuatan kitosan karena menghasilkan nilai kadar abu yang tidak berbeda nyata dengan perlakuan yang menghasilkan nilai kadar abu terendah (perlakuan kombinasi $\mathrm{NaOH} 50 \%$ dan suhu $100^{\circ} \mathrm{C}$ ) serta perlakuan tersebut merupakan perlakuan terbaik berdasarkan analisis nilai derajat deasetilasi dan rendemen.

\section{Kadar Air Kitosan}

Kadar air yang dihasilkan oleh kitosan hasil dari penelitian ini berkisar antara $0,25 \%-0,41 \%$. Presentase rata-rata kadar air kitosan dapat dilihat pada Tabel 4.

Kadar air kitosan pada penelitian ini berkisar antara 0,25\%-0,41\%. Kadar air tersebut tergolong rendah dan telah memenuhi syarat mutu kitosan yang telah ditetapkan oleh Badan Standardisasi Nasional (2013) yaitu maksimal 12\%. Faktor konsentrasi $\mathrm{NaOH}$, suhu dan kombinasi $\mathrm{NaOH}$ dan suhu tidak berpengaruh nyata terhadap kadar air kitosan yang dihasilkan. Berdasarkan rata-rata, perlakuan kombinasi $\mathrm{NaOH} 60 \%$ dan suhu $130^{\circ} \mathrm{C}$ menghasilkan nilai kadar air tertinggi dibanding perlakuan lain yaitu sebesar $0,41 \%$. Hal tersebut dapat terjadi karena perlakuan kombinasi $\mathrm{NaOH} \quad 60 \%$ dan suhu $130^{\circ} \mathrm{C}$ merupakan perlakuan yang juga menghasilkan nilai derajat deasetilasi tertinggi (73,15\%). Menurut Zakaria et al. (2012), nilai derajat deasetilasi yang semakin 
tinggi menandakan kitosan akan memiliki ikatan hidrogen yang semakin meningkat sehingga kitosan akan lebih mudah berikatan dengan molekul air yang ada di lingkungan.

Tabel 4. Presentase rata-rata kadar air kitosan (\%)

\begin{tabular}{cccc}
\hline \multirow{2}{*}{ Konsentrasi NaOH $(\mathrm{K})$} & \multicolumn{2}{c}{$\mathrm{Suhu}(\mathrm{S})$} & \multirow{2}{*}{ Rata-rata } \\
\cline { 2 - 3 } & $\mathrm{S} 1\left(100^{\circ} \mathrm{C}\right)$ & $\mathrm{S} 2\left(130^{\circ} \mathrm{C}\right)$ & \\
\hline $\mathrm{K} 1(50 \%)$ & $0,31 \pm 0,12$ & $0,32 \pm 0,1$ & $0,32 \pm 0,1$ \\
$\mathrm{~K} 2(55 \%)$ & $0,25 \pm 0,06$ & $0,28 \pm 0,11$ & $0,26 \pm 0,08$ \\
$\mathrm{~K} 3(60 \%)$ & $0,28 \pm 0,05$ & $0,41 \pm 0,1$ & $0,35 \pm 0,1$ \\
\hline Rata-rata & $0,28 \pm 0,08$ & $0,34 \pm 0,11$ & \\
\hline
\end{tabular}

Berdasarkan uji lanjut Duncan tidak terdapat perbedaan yang nyata antar perlakuan terhadap nilai kadar air kitosan yang dihasilkan. Perlakuan kombinasi $\mathrm{NaOH} 55 \%$ dan suhu $100^{\circ} \mathrm{C}$ menghasilkan nilai kadar air terendah $(0,25 \%)$ sehingga perlakuan tersebut dipilih sebagai perlakuan yang paling efisien digunakan untuk pembuatan kitosan karena perlakuan tersebut juga merupakan perlakuan terbaik dari analisis nilai derajat deasetilasi, rendemen dan kadar abu.

\section{KESIMPULAN DAN SARAN Kesimpulan}

Kombinasi $\mathrm{NaOH}$ dan suhu berbeda tidak berpengaruh nyata terhadap nilai derajat deasetilasi kitosan yang dihasilkan dari cangkang kerang kampak. Faktor konsentrasi $\mathrm{NaOH}$ memberikan pengaruh yang nyata terhadap nilai derajat deasetilasi $(\mathrm{P}<0,05)$. Perlakuan kombinasi $\mathrm{NaOH} 55 \%$ dan suhu $100^{\circ} \mathrm{C}$ merupakan perlakuan yang cukup baik dalam menghasilkan kitosan dari cangkang kerang kampak yang menghasilkan nilai derajat deasetilasi sebesar $71,70 \%$, rendemen sebesar 47,25\%, kadar abu sebesar 84,32\% dan kadar air sebesar $0,25 \%$.

\section{Saran}

Berdasarkan penelitian yang telah dilakukan, kerang kampak kurang optimal untuk dimanfaatkan sebagai bahan baku dalam produksi kitosan karena masih memiliki kadar abu yang tinggi. Perlu dilakukan pencarian bahan baku kitosan dari limbah cangkang kerang jenis lain yang memiliki kadar abu yang lebih rendah.

\section{DAFTAR PUSTAKA}

Apriani, L., Iskandar, G. M., dan Said, M. 2012. Pengaruh Variasi Konsentrasi $\mathrm{NaOH}$ terhadap Nilai Derajat Deasetilasi pada Pembuatan Chitosan dari Cangkang Kulit Kepiting. Jurnal Teknik Kimia, 1 (18) : 3540.

Azhar, M., Efendi, J., Syofendi, E., Lesi, R. M., dan Novalina, S. 2010. Pengaruh Konsentrasi $\mathrm{NaOH}$ dan $\mathrm{KOH}$ terhadap Derajat Deasetilasi Kitin dari Limbah Kulit Udang. Eksakta, $1:$ : 1-8.

Badan Standardisasi Nasional. 2006a. Cara Uji Kimia - Bagian 1: Penentuan Kadar Abu pada Produk Perikanan SNI 01-2354.1-2006. BSN. Jakarta. 4 hal.

Badan Standardisasi Nasional. 2006b. Cara Uji Kimia - Bagian 2: Penentuan Kadar Air pada Produk Perikanan SNI 01-2354.2-2006. BSN. Jakarta. 4 hal.

Badan Standardisasi Nasional. 2013. Kitosan Syarat Mutu dan Pengolahan SNI 7949: 2013. BSN. Jakarta. 8 hal.

Cakasana, N., Suprijanto, J., dan Sabdono, A. 2014. Aktivitas Antioksidan Kitosan yang Diproduksi dari Cangkang Kerang Simping (Amusium sp.) dan Kerang Darah (Anadara 
sp.). Journal of Marine Research, 3

(4) : 395-404.

Fauzan, A. 2001. Pengaruh Konsentrasi $\mathrm{NaOH}$ dan Suhu Proses terhadap Derajat Deasetilasi Kitosan. Skripsi. Institut Pertanian Bogor. 60 hal.

Hargono., Abdullah., dan Sumantri, I. 2008. Pembuatan Kitosan dari Limbah Cangkang Udang serta Aplikasinya dalam Mereduksi Kolesterol Lemak Kambing. Reaktor, 12 (1) : 53-57.

Hastuti, B., dan Tulus, N. 2015. Sintesis kitosan dari Cangkang Kerang Bulu (Anandara inflata) sebagai Adsorben Ion $\mathrm{Cu}^{2+}$. Artikel Ilmiah Seminar Nasional Kimia dan Pendidikan Kimia. 10 hal.

Liu, D., Wei, Y., Yao, P., and Jiang, L. 2006. Determination of Degree of Acetylation of Chitosan by UV Spectrophotometry Using Dual Standards. Carbohydrate Research, $341: 782-785$.

Mastuti, E. W. 2005. Pengaruh Konsentrasi $\mathrm{NaOH}$ dan Suhu Pada Peroses Deasetilasi Kitin dari Kulit Udang. Ekuilibrum, 4 (1) : 21-25.

Rinaudo, M. 2006. Chitin and Chitosan: Properties and Applications. Progress in Polymer Science, 31 : 603632.

Rochima, E. 2015. Pemanfaatan Limbah Kitin Rajungan Lokal untuk Produksi Kitosan: Upaya Meningkatkan Kesejahteraan Nelayan di Pesisir Cirebon.

http://pustaka.unpad.ac.id/wpcontent/uploads/2015/10/Pemanfaa tan-Limbah-Kitin-RajunganLokal.pdf. 9 Februari 2016. 17 hal.

Rokhiati, N. 2006. Pengaruh Derajat Deasetilasi Khitosan dari Kulit Udang terhadap Aplikasinya sebagai Pengawet Makanan. Reaktor, 10 (2) : 54-58.

Sinardi., Soewondo P., dan Notodarmojo, S. 2013. Pembuatan, Karakterisasi, dan Aplikasi Kitosan dari Cangkang Kerang Hijau (Mytulus virdis linneaus) sebagai Koagulan Penjernih Air. Konferensi Nasional Teknik Sipil, $7: 33-38$.

Subagiyo, H., and Widagdo, S. 2014. Diversity of Fisheries Resources and Fishing Gear Ownerships on Fishing Capture at Surabaya Coastal Waters Indonesia. The International Journal of Engineering And Science, 3 (8) : 2319-1805.

Sulistyoningrum, R. S., Suprijanto, J., dan Sabdono, A. 2013. Aktivitas Antibakteri Kitosan dari Cangkang Kerang Simping pada Kondisi Lingkungan yang Berbeda : Kajian Pemanfaatan Limbah Kerang Simping (Amusium sp.). Journal of Marine Research, 2 (4) : 111-117.

Tanasale, M. 2010. Kitosan Berderajat Deasetilasi Tinggi: Proses dan Karakterisasi. Seminar Nasional Basic Science, 2 : 187-193.

Wahyuni, S., Asnani., dan Nur I. 2008. Kajian Analisis Limbah Hasil Deproteinasi dan Demineralisasi pada Pembuatan Kitosan dari Kerang Abalone (Haliotis asiniar) Lokal. Warta Wiptek, 16 : 123-127.

Zakaria, Z., Izzah, Z., Jawaid, M., and Hassan, A. 2012. Effect of Degree of Deacetylation of Chitosan on Thermal Stability and Compatibility of Chitosan Polyamide Blend. Bioresources 7 (4) : 5568-5580. 